University of Nebraska - Lincoln

DigitalCommons@University of Nebraska - Lincoln

Agronomy \& Horticulture -- Faculty Publications

Agronomy and Horticulture Department

$10-1934$

\title{
Stability of Climax Prairie and Some Environmental Changes Resulting from Breaking
}

\author{
J. E. Weaver \\ University of Nebraska-Lincoln \\ Evan Flory \\ University of Nebraska-Lincoln
}

Follow this and additional works at: https://digitalcommons.unl.edu/agronomyfacpub

Part of the Plant Sciences Commons

Weaver, J. E. and Flory, Evan, "Stability of Climax Prairie and Some Environmental Changes Resulting from Breaking" (1934). Agronomy \& Horticulture -- Faculty Publications. 460.

https://digitalcommons.unl.edu/agronomyfacpub/460

This Article is brought to you for free and open access by the Agronomy and Horticulture Department at DigitalCommons@University of Nebraska - Lincoln. It has been accepted for inclusion in Agronomy \& Horticulture -Faculty Publications by an authorized administrator of DigitalCommons@University of Nebraska - Lincoln. 


\title{
ECOLOGY
}

\begin{tabular}{lll}
\hline \hline Vol. XV & October, 1934 & No. 4 \\
\hline
\end{tabular}

\section{STABILITY OF CLIMAX PRAIRIE AND SOME ENVIRON- MENTAL CHANGES RESULTING FROM BREAKING*}

\author{
J. E. Weaver and Evan L. Flory \\ University' of Nebraska
}

Continued study of the great midcontinental grasslands of North America throughout a period of years has impressed the writers with the high degree of stability of the climax prairie. This phenomenon has been carefully considered in a study of the types of prairie in the Missouri Valley over an area of several thousand square miles centering in eastern Nebraska but including five neighboring states. Present studies on the deterioration of the prairie under the impact of grazing, and changes in edaphic and atmospheric environment with the breaking and cropping of the land have further emphasized the stabilizing influence of a cover of grassland.

\section{Occurrence of Prairie Remnants}

Considerable areas of native prairie, undisturbed except by annual mowing, still occur in the more recently settled states such as Nebraska and South Dakota, but in Missouri and Iowa where breaking began 80 or more years ago they are infrequent. In fact one may drive for miles through areas of cultivated lands where extensive fields of corn, wheat, alfalfa, and other crops thrive in the fertile soil formerly occupied by native grasses. But close search reveals relict tracts of tall-grass prairie 20 to 160 or more acres in extent where the native sod still remains intact. Their former subjection to grazing by herds of buffalo, elk, and other native animals has been replaced by annual mowing, usually during September. The fires started by lightning or deliberately set by the Indians to make travel easier and more secure, to furnish earlier grazing and better conditions for hunting, or for other purposes, have practically disappeared. What minor changes the mowing, absence of grazing, etc., have brought about are known only in part. With few exceptions they have been too small to impress greatly the pioneers. The prairies as

* Contribution from the Department of Botany, University of Nebraska, no. 86. 
they are found today represent climax conditions and afford impressive lessons as regards stability.

\section{Nature of Stability}

Stability denotes a high degree of equilibrium between the vegetation and its habitat under the control of the existing climate. It does not preclude minor changes in the abundance of the constituent species. This regularly occurs from year to year as a response to the extremely irregular variations in the factors of the habitat-complex. The phenomenon, however, is often more apparent than real. The more important species are long lived and continuously present. They may be either less or more conspicuous because of their lack or abundance of flowering and fruiting, depending upon locally unfavorable or favorable conditions. Conspicuous fluctuations occur mostly among annuals or other relatively short-lived plants. Although the details of the pattern of the prairie mosaic may change, the shiftings are of minor importance. The relative constancy of the numbers of plants over a long period of time and the ordinary fluctuations within relatively narrow limits indicate the high degree of balance or stabilization. There are no great waves of emigrations, neither are there immigrations, for the prairie is a closed community and invaders, with rare exceptions, are excluded.

\section{Resistance to Invasion}

Large tracts of prairie are practically uninvaded by weeds except to the extent that trails or roads have been made through them or soil has been washed into the ravines from adjacent fields. Small subseres are frequently initiated as a result of the occupancy of local areas by stacks of hay. Gopher mounds may temporarily cover the vegetation; the burrows of badgers and other animals likewise cause disturbance. Here invading weeds temporarily find a home from which their offspring are soon expelled as the prairie species reclaim the soil. It is indeed impressive to find these relict areas of prairie entirely uninvaded, although surrounded on all sides by cultivated crops with their accompanying annual weeds or by pastures with their usually longer lived weedy flora. They are free from invasion although the kinds of invaders are numerous and their methods of competition diverse. ${ }^{1}$ In fact the number of possible invaders is quite as large as the more important prairie species themselves. A recent list of the immigrant flora of Iowa alone contains 263 species (Cratty, '29). Shimek ('31) states that 265 species make up the bulk of the prairie flora of Iowa. Steiger ('30) found 237 species of prairie plants on a single section (640 acres) of land near Lincoln. Weaver and Fitzpatrick ('34) list about 50 grasses and grass-like species as being of considerable importance. They found approximately 142 species of forbs occurring in at least 10 per cent of the 135 prairie areas studied.

${ }^{1}$ Poa pratensis constitutes a notable exception. It has spread widely under annual mowing (cf. Weaver and Fitzpatrick, pp. 179 to 182, '34). 
Small tracts of prairie, if undisturbed, are also remarkably free from invasion. Frequently strips of native prairie 10 to 20 feet wide, but miles in length, are found along railways. "In many cases these prairie strips have been preserved without appreciable deviation from the pure prairie type even where bordered on the one side by the roadbed with its ever-present belt of weeds, and on the other by farm lands which have been under cultivation from 30 to 60 years" (Shinek, '31). Similar areas are to be found along roadways throughout the more recently settled portions of the prairie region. Such small tracts of prairie, if undisturbed, contain all the species found in larger areas and the distribution is similar. But care must be taken not to place too much dependence upon them. If they have been grazed, very frequently burned, or otherwise disturbed in the past, the present flora of such localized areas may not be entirely representative of the prairie proper.

This is well illustrated by the absence of the genus Psoralea, and especially $P$. floribunda, from many apparently undisturbed prairies. In fact, in prairies only a half-mile away they may be abundantly represented. These legumes were perhaps entirely exterminated by grazing for a few years, after which the prairie, no longer pastured, " returned" without them.

\section{Reestablishmant of Prairie}

Sometimes prairie land is broken, cropped for a number of years, and then left untilled. When cultivation is discontinued on land adjacent to prairie and the surface soil is not otherwise disturbed, the land "goes back" to prairie. The weedy annuals and perennials which constitute the early stages of the subsere are gradually replaced by the original prairie grasses and forbs. The rate of reestablishment varies greatly, the time for the occurrence of stabilization depending in a large measure upon the water relations, soil type, and especially the size of the denuded area. Drier years often lessen the effective competition of the ruderals and turn the balance in favor of the native flora. The area may appear like prairie after the passing of 7 to 15 years. The final equilibrium attained between species--as far as it is ever attained in nature-and the reestablishment of the former interrelations between vegetation and soil would probably require a much longer time.

\section{Nature, of Control}

Control in grassland does not require complete occupancy. This is shown by the fact that the actual ground or basal cover seldom exceeds 25 per cent. It is usually about 15 per cent and in some of the densest types of grassland, such as Spartina michauxiana, less than 1 per cent. The control is exerted partly through competition for light, and especially for the water supply. In uplands the light values near the soil surface, such as are met by invading seedlings, often range from 20 to 60 per cent on days of full sunshine; under the dense cover of the taller lowland vegetation, from 1 to 10 per cent. One 
needs only to examine a bisect in the prairie soil to fully comprehend how every cubic inch is permeated with the fine absorbing rootlets of the grasses to a depth of several feet. Intermixed with these and often extending far below are the root systems of the forbs. The root masses thoroughly occupy the soil continuously from year to year.

Determinations of soil moisture over a long period of years have shown that the prairie species frequently exhaust all the available moisture in the surface 6 inches of soil-the layer upon which the roots of seedlings must largely depend. The well established vegetation each year develops rapidly from accumulated food supplies, the taller grasses often growing a centimeter per day. During years of drought practically the entire available water supply is used. The prairie is a field with many crops; some are growing at all times from spring until fall. Blossoming and ripening of fruit is a continuous process throughout the growing season. If water is abundant, as in years most favorable to growth, the invading seedlings may share the supply only to be deprived of sunshine by the rank foliage of the native flora.

Stability is increased by the long span of life of many prairie species. Perhaps only about 5 per cent are annuals. The dominant grasses such as the Andropogons, Sporobolus heterolepis, etc., once established, retain their vitality many years. This has been determined by continuous observation, by long-time permanent quadrats, and by a study of the slow centrifugal growth of the bunches which only after many years disintegrate. It has been further confirmed by a study of seedling establishment over a period of years; many seedlings may appear, but few ecize (Blake, '34).

The climax vegetation is the outcome of thousands of years of sorting out of species and adaptations to the soil and climate. In fact, it is more than this, for the vegetation itself has had no small part in determining the physical, chemical, and biological properties of the soil. It has also reacted upon climate. The vegetation represents not only an evaluation of the present edaphic and atmospheric factors but also those of the past. Climax prairie is in close adjustment with its environment.

Unless disturbed by man, and barring the entrance of a new dominant from another region, the prairie will maintain possession until there is a fundamental change in climate or a new flora develops as the outcome of longcontinued evolution.

\section{Comparison of the Prajrie Habitat with that of Cultivated Fields}

With the breaking of the prairie and the growth of cultivated crops, the environment is profoundly modified. Under natural conditions the living prairie cover is renewed in early spring and throughout the entire growing season the grassland continuously presents a cover of foliage for the absorption of radiant energy. In fields with annual crops such as corn, wheat, oats, 
rye, barley, and sorghums, the soil, for a time, is entirely bare. The grassland cover, viewed from above usually conceals from 60 to 100 per cent of the soil. This cover is very effective in absorbing the radiant energy since it usually consists of plants varying in leaf pattern and height, the foliage of which more or less overlaps. Often three to five more or less distinct absorbing levels occur. On a single square foot of lowland, for example, Fragaria or Viola may be overtopped by Steironema or Anemone and both by species of Asclepias, which in turn may be shaded by Elymus and the latter by Andropogon.

Even after mowing, the ground is not bare. The bases of the plants extend 2.5 to 3 inches high before new growth begins in autumn. A mulch of fallen leaves, fragments of stems, flowers and fruits, etc., forms a more or less continuous cover of varying thickness. This may have a dry weight of 50 to 225 grams per square meter on uplands and over 1000 grams on lowlands. Thus at all times the soil is protected from direct insolation. The maturing crop of corn may present a leaf surface four times as great as the actual acreage planted (Kiesselbach, '16), but this leaf surface is exceeded by that of the little or big bluestem by 50 to 100 per cent. In the field of wheat, the soil may be fairly well covered in spring but the crop is harvested by midsummer and, under the better farm practices, immediately laid bare by plowing. With crops of clover and alfalfa conditions more nearly approach those of the prairie, although here the accumulated foliage is almost entirely removed two or more times during the growing season.

The nature of the soil itself affects the reception of radiant energy on mowed prairie or on those where the cover of vegetation is less well developed. The prairie soil presents an excellent granular structure to a depth of 8-14 inches. Usually about 55 per cent by volume is pore space occupied by air and water. In fields long under cultivation this structure is much less evident and the soil is more compact. Prairie soil is always filled with living roots and rhizomes, decaying plant parts, and the network of channels left by them. Organic matter is high, often about 5 per cent by weight and very much more by volume in the surface six-inch horizon. Thus, owing both to the structure of the soil itself, but especially to its cover or lack of cover of vegetation, conditions for absorption of radiant energy are very different in cultivated field and native grassland.

Extensive comparisons of the environment and some physiological responses of prairie vegetation and cultivated corn (Flory, '34) and similar comparisons between prairie vegetation and wheat (Noll, '34) are under way in eastern Nebraska. The data to be presented here are preliminary measurements made by the writers and indicate some of the marked changes that occur when the native grassland is broken and cropped. 


\section{Light And Temperature}

The relative energy relations, as expressed in terms of light, have been determined in fields of corn and adjacent upland prairie. At one-half the height of the vegetation, when the foliage cover has reached its maximum, the light is frequently only 65 per cent of full sunshine in cornfields and 25 per cent in prairie. At the base of the plants it is often 50 and 5 per cent respectively. These determinations were made by means of Clement's photometers.

The stabilizing influence of prairie as compared to cultivated fields on temperature is marked. Since the extremes are often more critical and significant to plants than are the means, an extreme case will be cited. On a cloudless day, June 10, 1933, during a period of intense heat and prolonged drought, the data in table I were obtained between 3:30 and 4:00 P.M. Both field and prairie were on Lancaster loam occupying a moderate north slope and only 500 feet apart. The air temperatures were taken in the shade of the body of the observer.

TABLE I. Comparative temperatures in cornfield and prairie

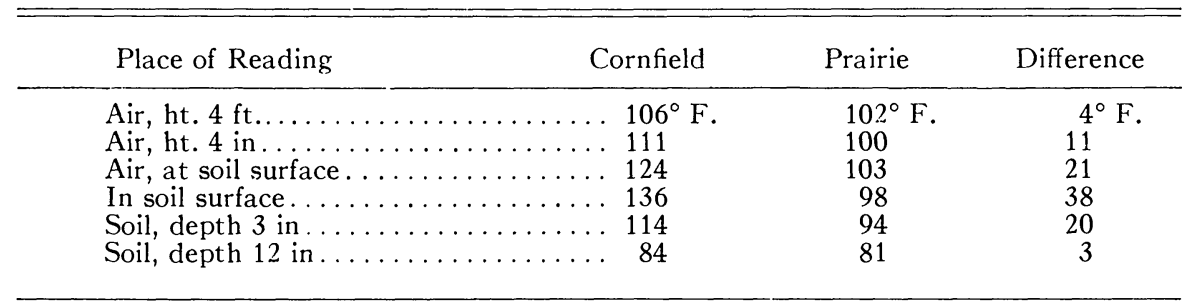

The marked differences in air temperatures reflect themselves both in greatly decreased humidity and increased transpiration. The increase in soil temperatures not only has a profound effect upon promoting water loss from the soil, and directly upon root functions, but also upon the activities of microorganisms. While nitrate production, for example, proceeds at a maximum rate in the moist prairie soil at $94^{\circ} \mathrm{F}$., at higher temperatures it becomes slower and may cease altogether at $131^{\circ}$ (Russel et al., '25).

At a depth of 3 inches, the mean soil temperature in the cornfield during three consecutive growing seasons was $8.3^{\circ} \mathrm{F}$. higher than in the prairie. Even at a depth of 8 inches an increase of $2.2^{\circ}$ occurred (Flory, '34).

\section{Humidity}

Temperature has a profound effect upon atmospheric humidity. In general one degree Fahrenheit rise in temperature decreases the humidity 1.5 to over 2 per cent depending upon the locality. Extreme differences in humidity in field and prairie are often surprisingly great. During the day cited, which was typical for a twenty-day period in June, the relative humidity at a 
height of four inches in the prairie was 31 per cent. It was only 12 per cent 4 inches above the hot, nearly bare soil in the field of corn. Over the cornfield, even at a height of four feet, the humidity was only 15 per cent as compared to 20 per cent in the prairie. A lower mean daily humidity in the cornfield prevailed throughout three growing seasons, and the mean day humidity was approximately 5 per cent higher in the prairie.

Comparative measurements of humidity and temperature were made just above a 20 -acre field of alfalfa and in a similar adjacent field where the crop had been harvested. The living plant cover increased the humidity 10 per cent and lowered the temperature $4^{\circ} \mathrm{F}$.

\section{WIND}

Mid-continental winds are practically always dry. A comparison of wind movement at various heights from the top of the foliage to the surface of the soil showed that in the prairie it was always less. Except on extremely windy days air movement beneath the dense foliage of grasses and forbs was not marked. Frequently there was none. A breeze of 9 miles per hour three feet above the surface of the prairie vegetation was reduced to 3.7 miles at the height of the foliage and to .1 mile at one-half this height. At the soil surface there was none. In the field of corn wind velocities at corresponding heights were $8.5,5,2.5$, and .9 miles per hour respectively. These measurements were made late in July when both prairie and corn had produced their maximum foliage. Wind movement among the corn plants at any time was greatly in excess of that among plants of the prairie.

\section{Evaporation}

Livingston's white, spherical atmometers were employed in comparing relative water losses in field and prairie. Average daily evaporation rates from July 15 to 24 are shown in table II.

TABLE II. Evaporation losses at various heights

\begin{tabular}{|c|c|c|c|c|c|}
\hline \multirow{2}{*}{ Place of Reading } & \multicolumn{2}{|c|}{ Cornfield } & \multicolumn{2}{|c|}{ Prairie } & \multirow{2}{*}{$\begin{array}{l}\text { Per cent } \\
\text { increase } \\
\text { in field }\end{array}$} \\
\hline & Height & $\begin{array}{l}\text { Evapora- } \\
\text { tion cc. }\end{array}$ & Height & $\begin{array}{l}\text { Evapora- } \\
\text { tion cc. }\end{array}$ & \\
\hline $\begin{array}{l}3 \mathrm{ft} \text {. above plants...... } \\
\text { At height of plants..... } \\
\text { One-half ht. of plants. } \\
\text { Near soil surface...... }\end{array}$ & $\begin{array}{l}9 \mathrm{ft} . \\
6 \mathrm{ft} . \\
3 \mathrm{ft} . \\
3 \mathrm{in.}\end{array}$ & $\begin{array}{l}55.7 \\
42.3 \\
31.1 \\
22.5\end{array}$ & $\begin{array}{l}4.25 \mathrm{ft} . \\
1.25 \mathrm{ft} . \\
7.5 \mathrm{in.} \\
3.0 \mathrm{in.}\end{array}$ & $\begin{array}{l}55.3 \\
3.3 .3 \\
15.1 \\
13.4\end{array}$ & $\begin{array}{r}0.7 \\
27.0 \\
106.0 \\
68.0\end{array}$ \\
\hline
\end{tabular}

The increase in the rate of evaporation of 27 to 106 per cent at various levels within the cultivated field is clearly of sufficient magnitude to be of great significance as regards rate of water loss in a dry climate. 
The increase in evaporation rate from similar pairs of atmometers placed near the soil surface was 80 per cent greater in a closely grazed pasture than in an immediately adjacent prairie.

\section{TRANSPIRATION}

The behavior of plants themselves in different habitats is of greatest importance since here the living organisms are responding to the total impact of the environment. Cylindrical cores of undisturbed prairie sod 5 inches in diameter and 18 inches deep were enclosed in metal cylinders which were sealed at the base. Corn was grown for three weeks in containers of appropriate size, which were sealed at the beginning of the experiment. Both the native and cultivated grasses were placed at the general level of the surrounding vegetation.

The average losses of the corn in its field and the prairie respectively were .34 and .18 grams per square centimeter of leaf surface. Those of the little bluestems were .36 and .30 grams. Thus under field environment the average loss from the several corn plants in excess of the average losses in the prairie was 89 per cent. Transpiration from the bluestem was increased 20 per cent when placed in the field of corn. During the same 10-day period in the latter half of July, the evaporation in the cornfield was 36 per cent in excess of that in the prairie. Thus the increase in light, temperature, wind movement, and evaporation and the decrease in humidity in the field have a profound effect upon the rate of transpiration.

\section{The Soil in Relation to Water}

Turning attention to the edaphic conditions, it should be pointed out that even if the actual precipitation is not decreased under annual cropping (and this may be found to be the case) certainly the distribution of water is more uniform over a prairie than over an area that is annually denuded. The snow lies much more uniformly and is less drifted by the wind in the tall-grass prairie and run-off resulting from heavy rains is much less. When rains occur, and especially the torrential ones characteristic of the dry prairie climate, the water does not beat directly upon the soil. Instead its force is broken by the cover of foliage and by the ever present surface mulch.

In the cultivated field, upon areas where the soil is bare or only partially covered by the growing crop, the raindrops beat upon the soil like millions of little hammers. The soil is compacted. The cohesive force between the soil particles is lessened as the surface becomes muddy. They shift their positions under the effect of the beating rainfall and fill up the soil pores. Thus the absorbing capacity is reduced. The excess water accumulates on the surface and on running off removes with it the surface soil particles, the humus and the dissolved salts. But in the prairie the soil is more receptive to water, since its structure has not been destroyed by cultivation, its organic content 
lessened by cropping, nor the network of roots and rhizomes, which thread it everywhere, annually destroyed.

The pore space in the upper 6 inches of a fairly mature upland prairie soil (Lancaster loam) was 50.5 per cent. This was decreased over 12 per cent within 6 years after the prairie was broken and continuously cropped to corn. Water penetration into this field soil was found to be only 60 per cent as rapid as into the unbroken prairie sod.

\section{Run-OFF AND ERosion}

Run-off in the prairie is usually slight unless the rains are heavy. Abundant humus creates a sponge-like condition in the top soil which increases its capacity to absorb and hold water, thus decreasing run-off. The water that does run off is usually clear, since the soil is firmly held in place by the bases of the plants, their widely and deeply spreading root systems, and the protection afforded by the soil mulch. The litter retains a half liter or more of water per square meter when it becomes saturated. This amount is insignificant in terms of soil moisture. The lodgement of the undecayed material between the stems of grass, however, forms an intricate series of minute dams and terraces which tend to hold the water until it can percolate into the soil. Surface erosion and gullies are not features of the prairie. It is only when the vegetation is closely grazed, and thus the amount of roots and rhizomes diminished that serious erosion begins. Trampling of the soil is additionally detrimental. On steep hillsides of similar slope two years of close grazing increased the run-off 50 to 80 per cent. Losses of valuable soil by excessive erosion are steadily impoverishing and even destroying vast areas of crop and grazing lands throughout the United States.

In a field planted to winter wheat a rain of 2.7 inches fell on a 4 degree slope during a period of two days early in December. Although the wheat had made an excellent fall growth, the run-off from 100 square feet of the dry, unfrozen soil was 38 per cent greater than on a similarly enclosed area of mowed prairie only a few yards distant.

Notwithstanding the increased run-off, the prairie farmer who left his "sloughs" and ravines to their natural cover of Spartina or other grasses has not had his farm cut into separate fields by deep, impassable gullies. $\mathrm{He}$ is also still able to secure yearly from these lowlands two or three crops of hay. In the old pastures and especially in the cultivated fields the annual losses of top soil by erosion are very great. When the soil is loosened by the plow, and especially when it gets into a poor physical condition as a result of long cultivation, it is often easily eroded both by wind and water. Fortunately sowing the soil to grass is a method of holding it in place. It is also a method of restoring to old, worn out soils the productivity and good tilth of virgin ones. The maintenance of an adequate supply of organic matter under climatic conditions indicated by prairie is very essential from the standpoint of 
water-holding capacity; supplying energy materials necessary to the bacterial flora concerned in nitrogen fixation; and in preserving the crumb structure which resists blowing away of the soil.

\section{Relative Demands for Water}

The actual available water-content of the soil in prairie and tilled fields of various crops and the relative demands of the natural vegetation and crop plants upon it should be determined. The prairie vegetation, rooted throughout several feet of soil, begins growth early in spring. The field for corn, on the contrary, lies fallow. Planting time occurs in May and the new crop may absorb only in the surface foot until well into June. The prairie continues growth notwithstanding drought in the surface soil, drought that may be so severe as to check greatly the growth of the new corn. With the progress of the season, the need for more and more water by the developing foliage in the prairie increases. This is in accord with the annual rainfall which usually reaches a maximum in June or July. These demands do not all occur at the same soil level. They are met in part by direct absorption from the soil even far below 5 feet. By midsummer a maximum transpiring area has been attained by the dominant grasses; the increase of water demands by the still growing autumnal forbs are probably largely off set by the waning or disappearance of vernal or estival species. Not so in the field of maize. The need for water constantly increases until flowering and fruiting. Roots are rapidly extended into the deeper soil-into the third, fourth, and fifth foot, which heretofore has furnished little or none of the supply. The demands for water are great and urgent. Actually these deeper soil layers are more depleted of their moisture early in autumn than are the corresponding ones in prairie.

Water relations in a field of winter wheat are quite different from those in either cornfield or prairie. Beginning growth in the surface layer in early fall, the wheat roots often reach a depth of 3 or 3.5 feet before growth is retarded or ceases because of low temperatures (Weaver, Kramer, and Reed, '24). In spring, resumption of growth precedes that in the prairie, and the maximum demands for water-by all plants at the same levels-precedes that in the grassland. By midsummer it ceases abruptly.

The effect of the prairie upon fertility and the resulting demands for water is exerted even after the native vegetation has been destroyed by plowing. The soil for a few years is mellow, moist, and rich, and produces abundant crops. Unlike the soil of plowed fields of alfalfa, the nutrients are liberated gradually. There is no overstimulation of the crop because of an excess of nitrogen and the accompanying intensification of periods of drought. 


\section{Need for Comparative Study of Natural and Field Environments}

There is a real need for a study of the prairie environment in comparison with that of cultivated fields. Soon the native prairie will be gone forever. Undoubtedly important changes in atmospheric humidity, regional loss of water by run-off, and lowering of the water table have already occurred. It seems clear that the more general influences of prairie climate may have already been modified by extensive cropping. Environment in limited and detached areas of native grassland, however, is still not far different at least in its micro-climate from the time when these areas were a part of the apparently unending sea of grassland.

A thorough study of Nature's crops and Nature's way of making the most of a sometimes adverse environment is of scientific importance. It is also fundamental to an understanding of the effect of prairie upon stabilizing such factors as temperature and humidity, and its effect upon stabilizing the soil. It furnishes a basis for measuring the degree of departure of cultural environments from the one approved by Nature as best adapted to the climate and soil.

The prairie crop is a mixed stand. Various legumes are blooming or ripening fruit from April until October. The same is true of the different species of grasses. There is a time for flax, another for mints and still another for roses. Not all of these crops are bountiful every year. Some may form no viable seed. Indeed there is no pressing need among the perennials for fruiting each year. Only on wet years does little bluestem normally fruit abundantly on dry uplands. How unlike the more delicate, annual crops of man. Neither is there a critical time for drought as in wheat, or corn, or clover, where a few days of adverse conditions may prove disastrous. Height and density of cover vary annually as does also the tonnage of hay. If drought comes early, growth is resumed upon the advent of wet weather. If it comes later, the earlier yielding prairie components have had a good year. Nature's crops are adjusted to fit into periods of dry cycles as well as wetter ones. These have recurred again and again throughout the centuries. Reserves of food of native plants are extensive and their resources for obtaining water excellent.

Cultivated plants are affected more readily by extremes of environment. Corn, for example, germinated well during 1933 and the early growth was rapid. Lack of rainfall before the phase of enlargement seriously threatened the crop. Heavy rains during this phase of growth produced unusually tall plants. During the dry early summer there were only a few times when the seeds of Sudan grass germinated. During drought in August the crop exhausted the available soil moisture even on low ground and ripened seed prematurely. The adjacent prairie grew continuously, however, and gave a good yield of hay.

These examples illustrate dangers of losses incurred in cropping. They 
are a part of the price civilized man pays for replacing the stable crop evolved by Nature by the unstable ones he selects. Crop production is essential to civilization and inevitable if the race is to endure. Nowhere in North America is the soil more favorable for crop growth than in the tall-grass prairie, although sufficient water often becomes a limiting factor, especially in the western part. It seems clear that a knowledge of the degree of departure, in growing each kind of crop, from the mean established by Nature is highly desirable.

The excessive demands of certain crops upon the prairie environment have just come to be realized. In native prairies the deeply rooted legumes and species of similar habit are relatively widely spaced. Under cropping conditions, however, the deeply rooted alfalfa is grown in dense stands. Frequently it so thoroughly depletes the upland subsoil of its moisture that it is difficult or impossible to grow again alfalfa, even after a lapse of a score of years, on soils thus drained of their water supply. When all the fields of a farm have once been enriched by crops of alfalfa and at the same time depleted of their subsoil moisture, the problem of maintaining soil productivity may become a very difficult one (Kiesselbach, Russel and Anderson, '29). While some consider this sapping of the subsoil a clever method of utilizing the natural resources in a dry climate, others are of the opinion that it may have an unfavorable reaction in lowering the water table and in the drying up of springs and streams. Both phenomena have resulted from disturbing $\mathrm{Na}$ ture's balance by breaking and cropping the land with its attendant run-off and erosion.

What are the relations of the various crops such as sorghums, oats and wheat to their new prairie habitat? Are the requirements of these and other crops within the limitations of prairie climate and soil, or are they demanding more, under present methods of cropping, than the habitat has to offer? Are we properly utilizing Nature's prairie garden or exploiting it?

A survey of agricultural progress in America shows that in many cases we have not used our lands wisely. In the humid east much land in forest should not have been cleared. In the semiarid west vast areas of range lands should never have been broken. In the development of scientific programs of land utilization there is great need of sorting out the various eroded or otherwise unproductive lands to be put again under a protecting cover of forest or grasses. As pointed out by Lipman ('32) these lands " not being in themselves profitable, are only a menace to the welfare of those who are trying to use profitably land which is legitimately agricultural."

\section{Upsetting the Balance of Nature}

After only half a century of prairie farming, soil investigators are greatly concerned with the rapid changes in soil fertility, structure, and water relations. We have not fully reckoned with the climatic factor in its relation to 
the building and conservation of soil fertility. Many other factor changes may well cause concern. What will be the penalties for disturbing Nature's balance?

The relation of the modified soil temperatures in bared areas---extremely high by day and lower than normal by night-to microorganisms has already been mentioned. Drying the surface a little more by removing the cover of vegetation, the mulch, and their shade will greatly change bacterial activity as well as that of other soil flora and fauna. An open field can not shelter in its upper layer the same population of microorganisms as can a shaded soil under the prairie grasses. Opening the stand and intermittently baring the ground establishes a new and little understood relation to light, temperature, humidity, and wind. Such modifications offer new and diverse environments. The upset of the long established equilibrium starts an extremely complicated series of changes. These include the relation to the environment of clisease producing organisms of both plant and animal origin. The relatively hardy and disease resistant flora of the prairie is at the same time replaced by one more tender and more varied in its susceptibility to disease.

Smith ('32) has recently pointed out some penalties for upsetting the balance of Nature in the prairies and plains. He states that insect and plantdisease problems caused by a modified fauna are actually increasing, both in number and severity. He concludes that man, the disturber, will have to employ artificial control efforts for a long period, or be seriously handicapped in his labors.

The increase of the rabbit population on overgrazed as compared with stabilized areas and a similar change in the abundance of the striped ground squirrel may be cited as examples of a disturbed natural balance. Various other rodents and ants probably occur in grasslands in larger numbers in consequence of overgrazing, surface erosion, or other disturbance. Under these conditions the tough sod disappears and the soil is more easily loosened. Rabbits, prairie dogs, and other rodents very much prefer the more succulent forbs, that are so plentiful in disturbed areas, to the climax grasses (Schaffner, '26, Vorhies and Taylor, '33). Overgrazed areas, more weeds and more rodents go hand in hand. The pocket gopher thrives and enormously increases in abundance, living upon the roots of alfalfa, and aided by the farmer who destroys his natural enemies. Returning in numbers to his native home, the prairie, he becomes a great disturber. Frequently ten times as many insects are obtained from grazed as from adjoining ungrazed areas. ${ }^{2}$ In fact. climax grassland offers a barrier to many species. Grasshoppers oviposit in bare soil and find conditions for growth, as do also white grubs, far more congenial in overgrazed areas (Fluke et al, '32). Similar changes resulting from the close grazing of prairie or the breaking of the sod are legion.

The great dust storms are an increasing menace and give cause for reflec-

${ }^{2}$ From correspondence with Dr. A. O. Weese. 
tion. Even if the millions of acres of bared soil do not promote convexion currents and consequent wind movements, certainly they do furnish the tons of dust that are carried in the atmosphere for miles and finally deposited in neighboring states. ${ }^{3}$ Great winds have probably always been prevalent in the prairie but not clouds of dust that darken the sky!

With the weakening or removal of the prairie sod, the menace of erosion is ever present. What in detail are its relations to the various systems and degrees of grazing? Under cultivation, the top soil from many hills has already been eroded until only the lower slopes and level crowns of the hills can be profitably farmed. Shall we await the arrival of the fertile soil from the slope to be held in the valley by the brush dam or other device or shall we forestall its removal by applying Nature's remedy of a permanent cover of vegetation on the steep hillsides? Since plant ecology is a study of the plant and of vegetation-native or otherwise-to its environment, surely these problems should vitally interest the ecologist.

The applications of lessons learned from a careful study of vegetation are manifold. In this period of the reclaiming of marginal lands, of planning great projects to ameliorate erosion, of developing scientific plans for land utilization, and of definite planning to establish cropping systems best calculated to produce economic returns from the different types of soil, we may profitably consider the natural environment. Not until the native environment in its relations to water, humidity, temperature fluctuations, and other critical factors of both air and soil has been compared with that of overgrazed and cropped areas will it be known how widely we are departing from $\mathrm{Na}$ ture's plan of a stable environment. Such comparative studies should be made now, before the opportunity with the destruction of the natural vegetation has forever passed.

'The writers are indebted to Prof. J. C. Russel and Dr. Herbert C. Hanson for reading the manuscript.

\section{Literature Cited}

Blake, A. K. 1934. Viability and germination of seeds and early life history of prairie plants. In press.

Cratty, R. I. 1929. The immigrant flora of Iowa. Ia. State Col. Jour. Sci. 3: 247269.

Fluke, C. L., L. F. Graber, and K. Koch. 1932. Populations of white grubs in pastures with relation to the environment. Ecology 13: 43-50.

Flory, E. L. 1934. Comparison of the environment and some physiological responses of prairie vegetation and cultivated corn. Unpublished MS.

Kiesselbach, T. A. 1916. Transpiration as a factor in crop production. Nebr. Agr. Exp. Sta., Res. Bull. 6.

Kiesselbach, T. A., J. C. Russel, and A. Anderson. 1929. The significance of subsoil moisture in alfalfa production. Jour. Amer. Soc. Agron. 21: 241-268.

${ }^{3}$ During a single windstorm on April 30, 1933, approximately 35 tons of soil were deposited per square mile over eastern Nebraska. This red soil was transported from several hundred miles southward. 
Lipman, J. G. 1932. The nitrogen outlook. Jour. Amer. Soc. Agron. 24: 227-237.

Noll, W. C. 1934. Comparison of the environment and some physiological responses of prairie vegetation and cultivated wheat. Unpublished MS.

Russel, J. C., E. G. Jones, and G. M. Bahrt. 1925. The temperature and moisture factors in nitrate production. Soil Sci. 19: 381-398.

Schaffner, J. H. 1926. Observations on the grasslands of the central United States. Ohio State Univ. Stud., Contr. Bot. 178.

Shimek, B. 1931. The relation between the migrant and native flora of the prairie region. Univ. Iowa, Stud. Nat. Hist. 14(2): 10-16.

Smith, R. C. 1932. Upsetting the balance of nature, with special reference to Kansas and the great plains. Science 75: 649-654.

Steiger, T. L. 1930. Structure of prairie vegetation. Ecology 11: 170-217.

Vorhies, C. T., and W. P. Taylor. 1933. The life histories and ecology of jack rabbits, Lepus alleni and Lepus californicus ssp., in relation to grazing in Arizona. Ariz. Agr. Exp. Sta., Tech. Bull. 49, pp. 541, 563-564.

Weaver, J. E., and T. J. Fitzpatrick. 1934. The prairie. Ecol. Monog. 4: 113-295.

Weaver, J. E., J. Kramer, and M. Reed. 1924. Development of root and shoot of winter wheat under field environment. Ecology 5: 26-50. 